and stainers, and it is suggested that some increase in staff is necessary. The Director decided, however, that before he would feel justified in recommending the executive committee to sanction this, he needs to be assured that the work already being done is on the right lines, and that the methods by which the different problems are being attacked are those best calculated to lead to the possibility of devising some means of control of these pests. The executive committee accordingly invited Prof. J. W. Munro, professor of entomology at the Imperial College of Science and Technology, to make a tour of the experiment stations in South Africa, Rhodesia and Nyasaland, where the work is going on, and to advise the Corporation whether this work should be continued on the present lines or modified, and to report whether the prospects of success justify extension of the work, or its maintenance on the present, or on a reduced, scale.

\section{British Bird Sanctuaries}

ThE biannual report of the Watchers' Committee of the Royal Society for the Protection of Birds, issued privately, covers the 1935 and 1936 seasons at the Society's bird sanctuaries in thirteen English counties, three Welsh counties and four Scottish counties, and contains the scheme and appeal for the purchase of Dengemarsh, a stretch of shingle on the south coast of Kent that, with the adjoining sanctuaries of Walkers Outland and the Open Pits shingle, will form a continuous 1,281 acres sanctuary for terns, waders and winter visitors. The Durham (Teesmouth) sanctuary has also a scheme for the extension of watching throughout the year to protect winter visitors. The most extensive reports are made by the watchers in Lakeland, Kent, Orkney and Shetland. All the Scottish sanctuaries report 1936 as being far better than 1935. The Orkney sanctuary at Stenaday reports hen-harriers, which include an albino strain, shelduck and eiders are increasing and merlins and short-eared owls decreasing there: red-necked phalaropes are holding their own where nesting on north Ronaldshay and have a new nesting ground at Papa Westray. In the Shetland sanctuaries gannets, eider, terns, great skuas, arctic skuas, fulmars, starlings, puffins, guillemots, mallard and shags have increased but kittiwakes, razorbills (in parts) and the common gull (which no longer nests on Hermaness) have decreased. Disease has wiped out the house-sparrows from Mid Yell. Very detailed returns are made by the Dungeness and Dengemarsh watchers of Kent, this sanctuary in addition to its ternary being very rich in migrants which last year included the black redstart. Stone-curlews and redlegged partridge have also nested successfully there, but oil and oiled birds are still frequent shore troubles.

\section{The R.H.S. Lily Year-Book}

The Royal Horticultural Society's lily Year-Book for 1936 (London, from the Society's Office, Vincent Square, Westminster, S.W.1, 5s. paper, 6s. cloth, 1936) includes a number of contributions to a scientific understanding of lily culture. Dr. Fred Stoker has made a study of the contractile roots of these plants. $\mathrm{He}$ shows that members of the Eulirion section of the genus Lilium possess such structures. Much interesting information as to how contractile roots of daughter bulbils penetrate the root-plate of the mother bulb, is imparted, and the microscopic anatomy has been investigated. An attractive feature of the volume is a bibliography of more than 550 references to published works upon lilies. This has been compiled by the Abbé Souillet, and although it appears comprehensive, it does not claim to have included a large number of articles which have appeared in English periodicals from time to time. A paper by Dr. M. A. H. Tincker shows that a suitable soil temperature of $65^{\circ}-70^{\circ} \mathrm{F}$. is an important factor in the propagation of lilies from bulb scales. It is interesting to note that soil heating by electric cables or hot-water pipes is suggested as an aid to this method of propagation. Many other papers communicate knowledge upon geographical or horticultural aspects of lily growing, and an interesting note by Mr. P. Rosenheim announces the discovery of an early treatise on the lily, contained in a German encyclopaedia by Kruenitz and Floerke, dated 1800 .

\section{Soviet Medical Films}

According to the Soviet Union Year Book Press service, moving pictures are being used in the U.S.S.R. for the treatment of nervous and mental diseases. Prof. Sukharebsky, of the Yakovenko Psychiatric Hospital in Moscow, has obtained remarkable success by showing epileptic patients films depicting calm lakes, picturesque landscapes, etc. He has also obtained good results by the use of a film in which he hypnotizes alcoholic addicts. A plan for a series of 102 short medical films has recently been approved by the Film Committee appointed by the Commissar of Health. The series includes brain operations and diseases of the spinal cord and brain. Other films are designed to assist surgeons to carry out rapid field operations in time of war. A film entitled "A Sick and a Healthy Heart" will be made under the direction of the heart specialist Prof. Zelenin, and another will deal with the development of the child between the ages of one month and two years. The last of the series will be a film entitled "Twenty Years of Soviet Medicine".

\section{Early Man in Japan}

EVIDENCE of the presence of palæolithic man is reported from an island in southern Japan. The discovery, it is stated by Science Service (Washington, D.C.), was made by Prof. Shigeyasu Tokunaga, geologist of Waseda University, who while exploring the Island of Itoe in the Loochoo group, found numerous fossil bones of deer, which bore marks of having been worked by human hands. The deer from which the bones were derived has long been extinct, having died out in the neolithic age. Numerous teeth, antlers and bones of the same species of deer of the same age, which Prof. Tokunaga dates at anything from 30,000 to 70,000 years ago, 
were found in a cave. If the bones in question have in fact been worked by man, this is the first evidence of palæolithic man to be found in Japan.

\section{Acute Poliomyelitis}

THE Ministry of Health has issued a memorandum upon acute poliomyelitis, an infectious disease commonly known under the name of infantile paralysis, though it may occur in adults (Memo. 166/Med. London: H.M. Stationery Office. 2d. net). The epidemiology, clinical characters and aftereffects of the disease are described and discussed, and the special diagnostic features are considered, together with a description of the changes in the cerebro-spinal fluid which serve to differentiate acute poliomyelitis from the normal and from other nervous diseases with which it may be confused.

\section{Ray Society}

Aт the annual meeting of the Ray Society on March 12, Prof. F. E. Weiss was elected treasurer in succession to Sir David Prain. Sir David Prain and Mr. A. W. Sheppard were elected vice-presidents, and Mr. Chas. Oldham, Mr. H. R. Darlington and Prof. F. Balfour-Browne were elected new members of Council. The Council's report stated that a translation of Linnæus's "Critica botanica" by the late Sir Arthur Hort, with an introduction by Sir Arthur Hill, would form part of the issue for 1937, which would be completed later by Mr. P. Ullyott's "British Freshwater Planarians". Others works in preparation are "British Tunicata" by Dr. John Berrill and "British Freshwater Beetles" by Prof. F. BalfourBrowne. Inquiries regarding membership of the Society should be addressed to the secretary, Dr. W. T. Calman, c/o British Museum (Natural History), Cromwell Road, London, S.W.7.

\section{Royal Academy of Sciences, Turin}

THE Atti of the Royal Academy of Sciences of Turin (72, Part 1, 1937) announces the opening of the one hundred and fifty-fourth year of the Academy's existence. It contains the address of the president, Prof. Vittorio Cian, relating the progress of the Academy during the year 1936. As in the case of other learned societies in Italy, new statutory regulations, approved by the Fascist Government, have come into operation. This publication also includes papers submitted to the Academy in the branches of mathematical, physical and natural sciences. It is intimated that the twenty-ninth Bressa Prize will be awarded during 1937 to a scientific worker of any nationality who shall have, in the opinion of the Academy, made during the period 1933-36 "the most noteworthy and useful discovery or produced the most celebrated work in the physical and experimental sciences, natural history, pure and applied mathematics, chemistry, physiology and pathology, not excluding geology, history, geography and statistics". The prize is valued at 9,000 lire, and candidates who wish to have their work considered by the Academy are invited to submit printed copies to the Secretary (3 Via Maria Vittoria, Turin) not later than March 31, 1937.

\section{Comets}

A telegram from the U.A.I. Bureau, Copenhagen, announces the discovery of a new comet, $1937 d$ (Kozawa), on March 9 in R.A. $11^{\mathrm{h}} 17 \cdot 3^{\mathrm{m}}$, N. Decl. $6^{\circ} 19^{\prime}$, magnitude 10 . The object is diffuse with central condensation, and a tail less than $1^{\circ}$ in length. The telegram has the remark "Unconfirmed", and further details are awaited. The Rev. Dr. M. Davidson, using observations on February 4 at Harvard. February 15 at Lick, and February 26 by Steavenson at Norwood, finds that Comet $1937 b$ (Whipple) is moving in an elliptical orbit, the period being about 250 years. More recent observations have been sent in by Hay and Kellaway, and Dr. Davidson is recomputing the elements with the longer time-intervals to determine the exact period. The date of perihelion passage was previously given as January, owing to an error in the telegram; it should have been June.

\section{Announcements}

The Right Hon. W. G. A. Ormsby-Gore, Secretary of State for the Colonies, and Sir Henry Tizard, rector of the Imperial College of Science and Technology, have been elected to the Board of Trustees of the British Museum, in succession to Mr. H. A. L. Fisher and Sir David Prain, who have resigned.

Prof. S. A. Waksman, professor of soil microbiology in the Rutgers University, New Brunswick, U.S.A., has been elected correspondant of the Section of Rural Economy of the Paris Academy of Sciences, in succession to the late Sir Arnold Theiler.

AT the annual general meeting of the Institution of Petroleum Technologists held on March 9, the Redwood Medal was presented to Mr. Harry Ricardo, in recognition of his contributions to the advancement of the science and technology of petroleum. Colonel S. J. M. Auld, chief technologist of the Vacuum Oil Co., Ltd., was inducted as president of the Institution at the same meeting in succession to Sir John Cadman.

AT the annual general meeting of the Microchemical Club, held on March 13, the following officers were elected : Hon. Treasurer, Dr. L. H. N. Cooper; Hon. Secretary, J. R. O'Brien; Hon. Librarian, Miss I. Hadfield; Members of the Committee : Prof. H. V. A. Briscoe, Dr. J. Matthew and Dr. S. J. Folley.

THe British Drug Houses, Ltd., have issued a guide in eleven pages to the Addendum (1936) to the British Pharmacopœia 1932. This guide, which should be very useful to those who have not made a detailed study of the Addendum, will be sent free of cost to members of the medical profession.

Erratum.-The name of the new secretary of the International Commission of Zoological Nomenclature (see Nature, March 13, p. 442) is Mr. Francis Hemming. 